\title{
Mimetics of the Arg-Gly-Asp Sequence: Synthesis and Studies of the Antiaggregative Properties
}

\author{
O. V. Gribovskaya ${ }^{a, 1}$, V. P. Martinovich ${ }^{a}$, E. V. Rodko ${ }^{b}$, E. D. Rasyuk ${ }^{b}$, \\ T. V. Ryabtseva ${ }^{c}$, and V. P. Golubovich ${ }^{a}$ \\ ${ }^{a}$ Institute of Bioorganic Chemistry, National Academy of Sciences of Belarus, Minsk, 220141 Belarus \\ ${ }^{b}$ Republican Scientific and Practical Center for Transfusiology and Medical Biotechnologies, Minsk, 220053 Belarus \\ ${ }^{c}$ Minsk Scientific and Practical Center of Surgery, Transplantology, and Hematology, Minsk, 220045 Belarus \\ Received March 16, 2021; revised March 27, 2021; accepted March 29, 2021
}

\begin{abstract}
It is known that the Arg-Gly-Asp sequence in the fibrinogen molecule is key in binding to the receptors on the surface of platelets. We searched for the compounds which were able to inhibit the binding and synthesized the following analogs of this sequence: 2 -acetoxybenzoyl-Arg- $\beta$ Ala-Asp, 4-piperidinecar-

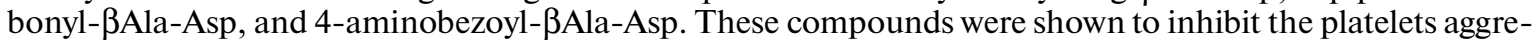
gation in a different degree. The 2-acetoxybenzoyl-Arg- $\beta$ Ala-Asp analog demonstrated the highest inhibitory activity. A decrease in the expression of the CD62p and CD63 markers on platelets was also found after the action of the Arg-Gly-Asp analogs, confirming the ability of these compounds to block the fibrinogen binding sites for the GP IIb/IIIa glycoprotein receptors.
\end{abstract}

Keywords: Arg-Gly-Asp-mimetics, the platelet aggregation, peptide synthesis, the GP IIb/IIIa receptor, the platelet markers

DOI: $10.1134 / \mathrm{S} 106816202106008 \mathrm{X}$

\section{INTRODUCTION}

Cardiovascular diseases are the main cause of mortality and disability in the nearly all advanced countries. Myocardial infarction due to blood-vessel occlusion by a cardiac thrombus causes the prevailing number of fatal outcomes. The glycoprotein receptors of platelets are most often responsible for thrombus formation, because the fibrinogen binding to the activated GP IIb/IIIa receptors of platelets is a final step of the platelet aggregation. The GP IIb/IIIa receptor belongs to the superfamily of the structure-relative glycoprotein receptors which consist of the two subunits: GP IIb or $\alpha_{\text {IIb }}\left(\alpha\right.$-subunit) and GP IIIa or $\beta_{3}$ ( $\beta$-subunit). Both subunits are present in various cells and are called as integrins [1] or cytoadhesins [2].

Several integrins, including GP IIb/IIIa, are known to recognize the common amino acid sequence, the Arg-Gly-Asp tripeptide. This fragment is present in chains of the majority of the differentially functioning adhesive glycoproteins. The importance of the Arg-Gly-Asp sequence is confirmed by inhibi-

Abbreviations: GP, glycoprotein; $\beta$ Ala, $\beta$-alanine; DIPC, $N, N-$ diisopropylcarbodiimide; TEA, triethylamine; $\mathrm{HOSu}, \mathrm{N}$ hydroxysuccinimide; HOBt, $N$-hydroxybenzotriazole; ESI, ionization by electrospray in an electric field; TEP, thrombocyteenriched plasma.

${ }^{1}$ Corresponding author: phone: +3 75-173-74-82-63; e-mail: olymelnik@yandex.ru. tion of the adhesion process of glycoproteins in the presence of short Arg-Gly-Asp-containing peptides [3]. Although, integrins have the common recognition site, they interact highly specifically with different glycoproteins $[1,2]$.

To date, the functional groups in the structure of the Arg-Gly-Asp mimetics that are involved in the ionic and hydrophobic interaction with the receptor have been determined [4].

Variations of the Arg-Gly-Asp structure [5, 6] allow the preparation of compounds with different physiological life times. The low-molecular-weight Arg-Gly-Asp-containing peptides and peptide mimetics are known to be widely applied to the treatment of ischemia of high and medium risk, acute coronary syndrome, and during angioplasty in combination with clopidogrel $[7,8]$. For example, eptifibatide (integrilin) that is the Arg-Gly-Asp-like cyclic heptapeptide has sufficiently high specificity to GP IIb/IIIa and does not significantly affect the activity of other integrins $[9,10]$. Several GP IIb/IIIa inhibitors based on the peptide mimetics of the Arg-Gly-Asp sequence have also been created for oral administration (xemilofiban, orbofiban, sibrafiban, and lotrafiban) [11]. These therapeutic drugs have been proposed for a long preventive treatment of thrombosis. Unfortunately, numerous studies of these compounds demonstrated that they had no advantages over aspirin and, even, 
exhibited high toxicity [12]. Therefore, they were not recommended for clinical use.

Thus, the creation of novel enzymatically resistant and long-acting Arg-Gly-Asp peptides and peptide mimetics for oral administration is an urgent problem for treatment and prophylaxis of cardiovascular diseases and strokes.

The goal of this study was the preparation of new analogs of the Arg-Gly-Asp sequence which could inhibit platelet aggregation.

\section{RESULTS AND DISCUSSION}

The Arg- $\beta$ Ala-Asp tripeptide served as a basis for a creation of mimetics of the Arg-Gly-Asp sequence. This tripeptide was previously shown to effectively inhibit the platelet aggregation [13]. We prepared a conjugate of the Arg- $\beta$ Ala-Asp tripeptide with aspirin. This conjugate could block blood clotting in two ways: by inhibiting platelet activation by thromboxane $A_{2}$ and by direct blocking of the binding sites of the GP
IIb/IIIa glycoprotein receptors. Therefore, 2-acetoxyArg- $\beta$ Ala-Asp tripeptide (V) with its $\alpha$-amino group that was acylated with acetylsalicylic acid (the compound with its inherent antithrombotic activity) was synthesized.

The Boc- $\beta$ Ala-Asp(OMe)-OMe (I) dipeptide was the starting compound in the synthesis of the mimetics. This peptide was prepared by a condensation of dimethyl ester of aspartic acid with the Boc- $\beta A l a-O H$ derivative. $N, N^{\prime}$-Dicyclohexylcarbodiimide with the addition of $N$-hydroxybenzotriazole was used as a condensing agent (Scheme 1). Further, we synthesized succinimide ester of acetylsalicylic acid, and acylated $\alpha$-amino group of arginine with this ester. The modified 2-acetoxybenzoyl-Arg- $\beta$ Ala-Asp(OMe)OMe tripeptide (IV) was prepared by a condensation of 2-acetoxybenzoyl-arginine with H- $\beta$ AlaAsp(OMe)-OMe. The final stage of the synthesis was an alkaline hydrolysis of the esters of aspartic acid. The synthesis involved six stages. The total yield of compound (V) was $46 \%$.

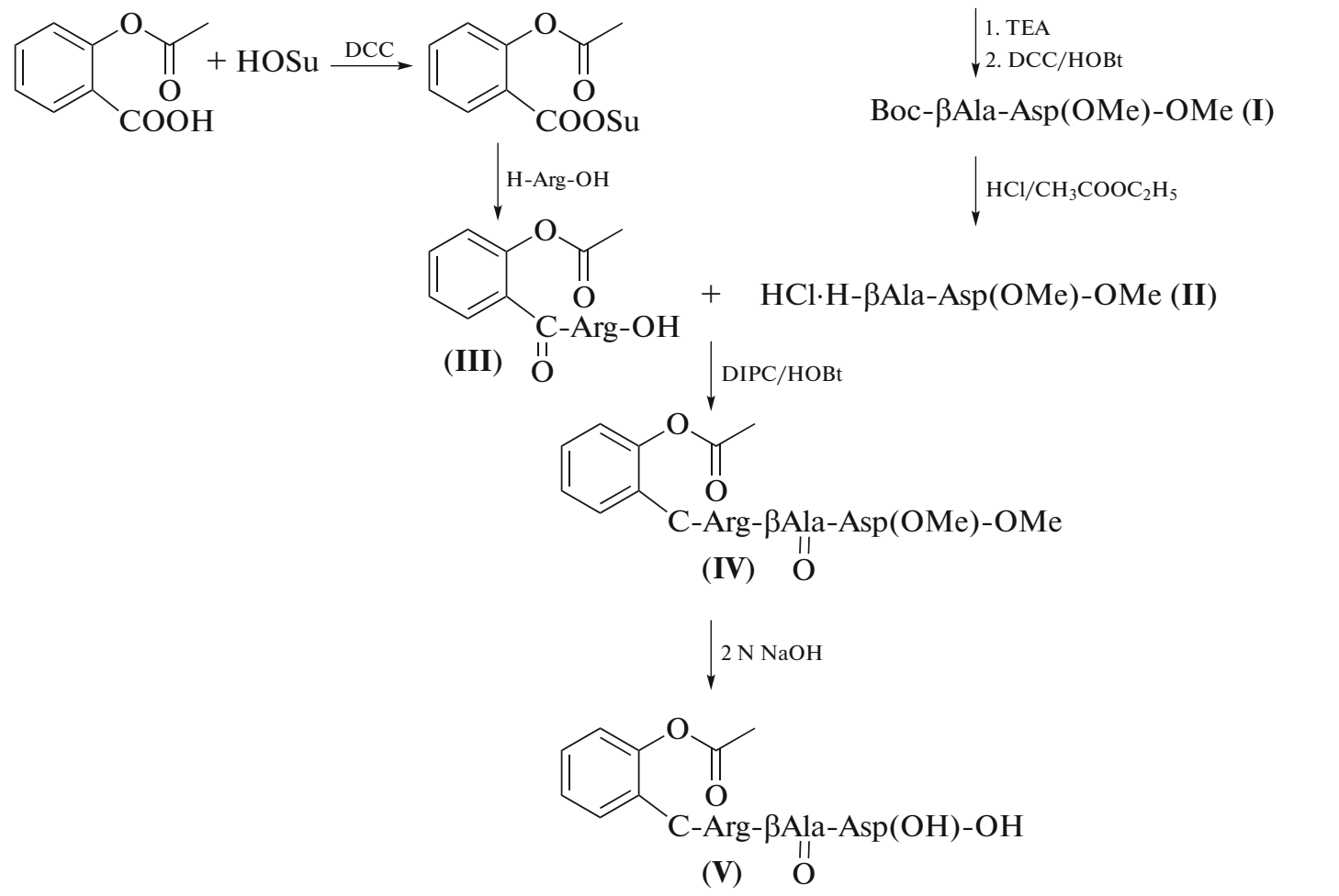

Scheme 1. The synthetic scheme of 2-acetoxybenzoyl-Arg- $\beta$ Ala-Asp.

We proposed on the basis of papers $[14,15]$ that a replacement of arginine in the Arg- $\beta$ Ala-Asp sequence by 4-piperidinecabonic acid or 4-aminobenzoic acid would increase the antithrombotic activity of the compounds. This proposal could be explained by a stabilization of the biologically active conformation by the cyclic fragments of the structures of the peptide mimetics which imitated the arginine side chain.

The synthesis of 4-aminobenzoyl- $\beta$ Ala-Asp compound (VIII) was performed according to Scheme 2. The Boc-derivative of 4-aminobenzoic acid was prepared by a treatment of the acid with di- 
tert-butyl-dicarbonate in a water-dioxane mixture. This derivative was further condensed with the $\mathrm{H}-\beta \mathrm{Ala}-\mathrm{Asp}(\mathrm{OMe})$-OMe dipeptide (II) with a high yield of $86 \%$. Compound (VI) was deprotected in two steps: the alkaline hydrolysis (for a saponification of the esters of aspartic acid) and the acidic hydrolysis (for a removal of the acid-labile Bocgroup).

$$
\begin{aligned}
& \text { Boc-R-OH + HCl-H-ßAla-Asp(OMe)-OMe (II) } \\
& \text { 1. TEA } \\
& \text { 2. } \mathrm{DCC} / \mathrm{HOBt} \\
& \text { Boc-R-ßAla-Asp(OMe)-OMe (VI), (IX) } \\
& 2 \mathrm{~N} \mathrm{NaOH} \\
& \text { Boc-R-ßAla-Asp(OH)-OH (VII), (X) } \\
& \downarrow \mathrm{HCl} / \mathrm{CH}_{3} \mathrm{COOC}_{2} \mathrm{H}_{5} \\
& \text { HCl-H-R-ßAla-Asp(OH)-OH (VIII), (XI) } \\
& \text { (VI), (VII), (VIII) } \mathrm{R}=-\mathrm{HN} \longrightarrow-\mathrm{C}_{\mathrm{O}} \\
& (\mathbf{I X}),(\mathbf{X}),(\mathbf{X I}) \mathrm{R}=-\mathrm{N}>-\mathrm{C}_{\mathrm{N}}^{\mathrm{N}}
\end{aligned}
$$

Scheme 2. The synthetic scheme of 4-piperidinecarbonyl- $\beta$ Ala-Asp and 4-aminobenzoyl- $\beta$ Ala-Asp.

4-Piperidinecabonyl- $\beta$ Ala-Asp (XI) was synthesized as described above. The total yields of 4-piperidinecabonyl-ßAla-Asp (XI) and 4-aminobenzoyl$\beta$ Ala-Asp (VIII) proved to be 40 and $51 \%$, respectively. The target compounds were identified by mass spectrometry and ${ }^{1} \mathrm{H}$ NMR spectroscopy. Their homogeneity was confirmed by TLC and analytical HPLC.

The antiaggregation activity of the compounds obtained was examined on the platelet-enriched human blood plasma with the use of ADP as an inducer of the platelet aggregation (Figs. 1 and 2). All the analogs of the Arg- $\beta$ Ala-Asp sequence (2-acetoxybenzoyl-Arg- $\beta$ Ala-Asp (V), 4-piperidinecarbonyl-

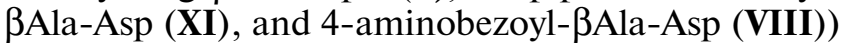
were able to inhibit the platelet aggregation to a variable degree, and all of them were more active than the starting Arg- $\beta$ Ala-Asp tripeptide.

2-Acetoxybenzoyl-Arg-BAla-Asp (V) proved to be the most active inducer of the platelet aggregation. After the addition of compound (V), the aggregation degree decreased from 42.6 to $15.0 \%$ and from 83.7 to $24.1 \%$ for the first and the second donors, respectively.

The platelet activation is known to be associated with a change in the expression of several surface receptors [16]. Such markers as CD36 (the thrombospondin receptor), CD61 (the $\beta 3$ integrin chain), and CD41 (the $\alpha$-chain of integrin in the CD61/CD41complex) are most often used for identification of the activated platelets during immunophenotyping. The
GPIIb/IIIa, CD42a [GPIX], CD42b [GPIb]), and CD62P (P-selectin) are also known. These glycoproteins are expressed by platelets and megacaryocytes and provide a cellular adhesion and the fibrinogen binding. These events resulted in the aggregation of platelets and their fixation on the endothelium [17]. $\mathrm{P}$-selectin (CD62P) is present in the platelet $\alpha$-granules and acts as a calcium-dependent protein, which is migrated to a plasmatic membrane during the platelet activation and participates in the platelet interaction with the endothelial cells and leukocytes. The integrin receptors are located on the platelet membrane in a complex with tetraspanins (CD9 and CD63) which support the signal transduction and the stable adhesion [18].

We determined an expression of the platelet markers after the contact and incubation of the Arg- $\beta$ AlaAsp peptide and its analogs with samples of the cellular thromboconcentrate by the flowing cytofluorimetry (BD FACSCantoII) in order to confirm the ability of compounds $(\mathbf{V}),(\mathbf{X I})$, and (VIII) to directly block the binding sites of the GP IIb/IIIa glycoprotein receptors. The expression was evaluated according to the percentage of the platelets that were bound to the fluorescent-labeled antibodies relatively to the markers (Table 1).

The changes in the expression of the CD62p marker $(\Delta \%$ from 8.10 for Arg- $\beta$ Ala-Asp to 3.10 for 2 -acetoxybenzoyl-Arg- $\beta$ Ala-Asp) and the CD63 marker $(\Delta \%$ from 7.15 for Arg- $\beta$ Ala-Asp to 1.40 for compound $(\mathbf{V})$ ) pointed to a decrease in the expression 


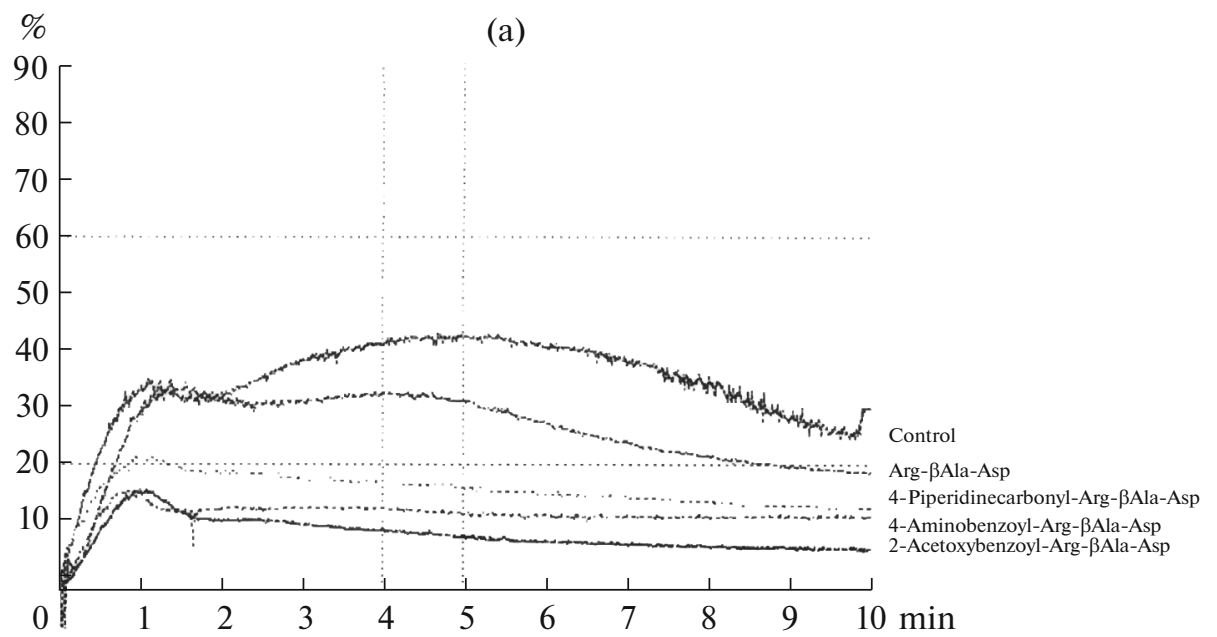

(b)

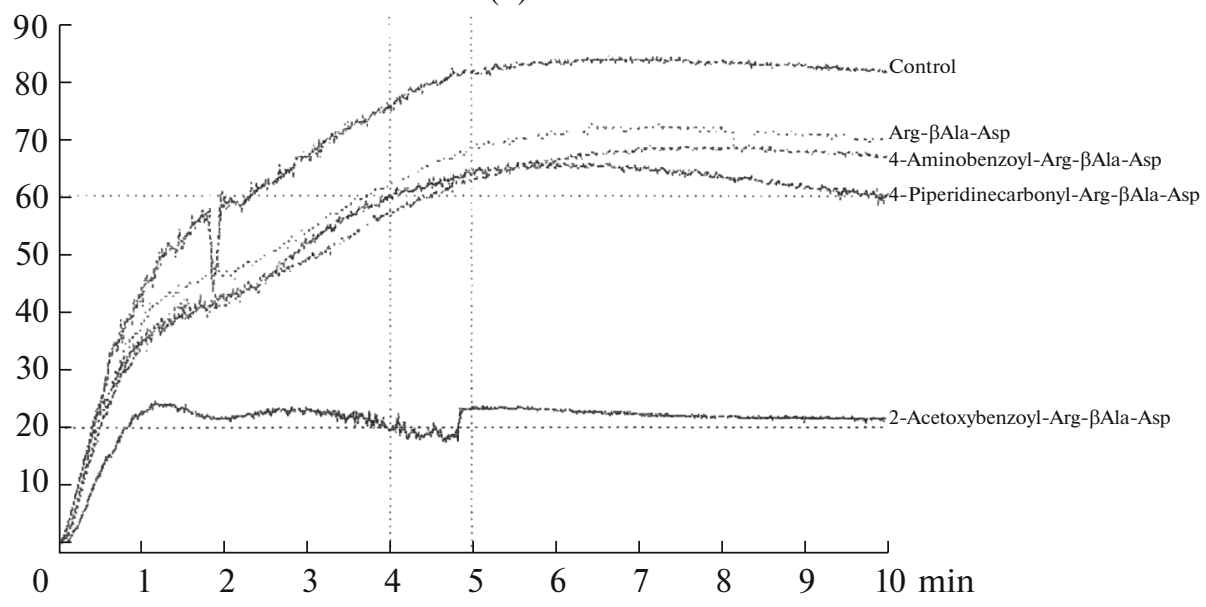

Fig. 1. The platelet aggregation in the presence of Arg- $\beta$ Ala-Asp and its analogs in a concentration of $10^{-5} \mathrm{M}$ in the plasma of the first (a) and second (b) donors.

Table 1. An expression of the platelet markers after the contact and the incubation of the Arg- $\beta$ Ala-Asp peptide and its analogs with the samples of the cellular thromboconcentrate

\begin{tabular}{|c|c|c|c|c|}
\hline \multirow{3}{*}{ The substance } & \multicolumn{4}{|c|}{ Marker on the platelet surface } \\
\hline & \multicolumn{2}{|c|}{ CD62p } & \multicolumn{2}{|c|}{ CD63 } \\
\hline & expression, $\%$ & $\begin{array}{c}\text { change } \\
\text { in the expression, } \Delta \%\end{array}$ & expression, $\%$ & $\begin{array}{c}\text { change } \\
\text { in the expression, } \Delta \%\end{array}$ \\
\hline The control experiment & $\begin{array}{c}41.95 \\
(3.55 ; 67.90)\end{array}$ & - & $\begin{array}{c}40.80 \\
(10.95 ; 67.45)\end{array}$ & - \\
\hline Arg- $\beta$ Ala-Asp & $\begin{array}{c}23.85 \\
(3.05 ; 54.72)^{*}\end{array}$ & $\begin{array}{c}8.10 \\
(0.55 ; 22.40)\end{array}$ & $\begin{array}{c}24.04 \\
(8.95 ; 42.40)^{*}\end{array}$ & $\begin{array}{c}7.15 \\
(1.85 ; 24.75)\end{array}$ \\
\hline $\begin{array}{l}\text { 2-Acetoxybenzoyl-Arg- } \\
\text { BAla-Asp (V) }\end{array}$ & $\begin{array}{c}35.35 \\
(3.15 ; 63.15)^{*}\end{array}$ & $\begin{array}{c}3.10 \\
(0.60 ; 8.25)\end{array}$ & $\begin{array}{c}39.70 \\
(9.95 ; 64.30)^{*}\end{array}$ & $\begin{array}{c}1.40 \\
(0.20 ; 2.30)\end{array}$ \\
\hline $\begin{array}{l}\text { 4-Aminobenzoyl- } \beta \text { Ala-Asp } \\
\text { (VIII) }\end{array}$ & $\begin{array}{c}21.25 \\
(3.00 ; 52.20)^{*}\end{array}$ & $\begin{array}{c}4.55 \\
(0.55 ; 13.20)\end{array}$ & $\begin{array}{c}31.35 \\
(9.15 ; 57.55)^{*}\end{array}$ & $\begin{array}{c}5.90 \\
(1.15 ; 12.05)\end{array}$ \\
\hline $\begin{array}{l}\text { 4-Piperidinecarbonyl- } \beta \text { Ala- } \\
\text { Asp (XI) }\end{array}$ & $\begin{array}{c}26.15 \\
(3.30 ; 46.71)^{*}\end{array}$ & $\begin{array}{c}6.55 \\
(0.30 ; 24.69)\end{array}$ & $\begin{array}{c}33.95 \\
(9.45 ; 59.50)^{*}\end{array}$ & $\begin{array}{c}4.50 \\
(1.35 ; 9.50)\end{array}$ \\
\hline
\end{tabular}

* Statistically significant changes, the Friedman method ANOVA, $p \leq 0.05$. 
of the CD62p and CD63 markers on platelets after the action of the examined substances. Thus, the synthesized compounds (V), (VIII), and (XI) could block the fibrinogen binding sites to the GP IIb/IIIa glycoprotein receptors.

An insignificant decrease in the expression of the CD62p and CD63 markers on platelets after the action of 2-acetoxybenzoyl- Arg- $\beta$ Ala-Asp (V) is more probably associated with an ability of this compound to inhibit synthesis of thromboxane $\mathrm{A}_{2}$, which is an inducer of the platelet aggregation.

\section{EXPERIMENTAL}

Amino acids, reagents, and solvents for this study were purchased from Sigma (United States), Fluka (Switzerland), and Acros Organics (Belgium). The synthesis of the compounds and the removal of the protecting groups were monitored by TLC on plates with the fixed silica gel layer (Sorbfil, Russia) in the following chromatographic systems: A, chloroformmethanol-25\% aqueous ammonia $(6: 4: 1)$; B, butanol-acetic acid-water $(4: 1: 1)$; $\mathrm{C}$, ethyl acetatepyridine-acetic acid-water $(5: 3: 2: 1)$. The substances were identified on the plates by treatment with chlorine and benzidine.

Analytical HPLC was performed on an Agilent 1200 chromatograph (United States) equipped with a QQQ (Triple Quadrupole) Agilent 6410 mass detector and an Agilent Zorbax SB C18 RR column $(2.1 \times 30 \mathrm{~mm})$. The column was eluted with a concentration gradient of acetonitrile in $0.05 \%$ aqueous solution of formic acid from 10 to $95 \%$ at a flow rate of $0.5 \mathrm{~mL} / \mathrm{min}$.

${ }^{1} \mathrm{H}$ NMR spectra were recorded on an AVANCE 500 spectrometer (Bruker BioSpin, United States) with a working frequency of $500 \mathrm{MHz}$ for the ${ }^{1} \mathrm{H}$ nuclei in $\mathrm{CD}_{3} \mathrm{OD}$. The chemical shifts and constants of the spin-spin interaction $(J)$ were expressed in parts per million (ppm) and $\mathrm{Hz}$, respectively. A resonance from the $\mathrm{CD}_{3} \mathrm{OD}$ solvent $\left(\delta_{\mathrm{H}} 3.34 \mathrm{ppm}\right)$ was used as an internal standard.

Melting points (uncorrected) were determined on a Kofler bench. A specific rotation of the compounds was measured on a Jasco J-20 spectropolarimeter (Japan).

Boc-ßAla-Asp(OMe $)_{2} \quad$ (I). TEA $\quad(2.80 \mathrm{~mL}$, $20.2 \mathrm{mmol}$ ) was added to the solution of hydrochloride of aspartic acid dimethyl ester $(3.06 \mathrm{~g}, 15.5 \mathrm{mmol})$ in DMF $(12.5 \mathrm{~mL})$. The reaction mixture was stirred for $20 \mathrm{~min}$, and Boc- $\beta \mathrm{Ala}-\mathrm{OH}(2.93 \mathrm{~g}, 15.5 \mathrm{mmol})$ was added. The reaction mixture was cooled to $0^{\circ} \mathrm{C}$, and HOBt (2.20 g, $16.3 \mathrm{mmol})$ and DCC (4.80 g, $23.3 \mathrm{mmol})$ were sequentially added. The reaction mixture was stirred for $1.5 \mathrm{~h}$ at $0^{\circ} \mathrm{C}$ and $4 \mathrm{~h}$ at room temperature. The precipitate was filtered off and washed with DMF $(4.0 \mathrm{~mL})$ on a filter. The filtrate was diluted with ethyl acetate $(40.0 \mathrm{~mL})$, washed with $9 \%$ solution of citric acid, $5 \%$ solution of $\mathrm{NaHCO}_{3}$, the saturated solution of $\mathrm{NaCl}$, and water, and dried over $\mathrm{Na}_{2} \mathrm{SO}_{4}$. Ethyl acetate was evaporated, and the formed oily residue was reprecipitated from diethyl ether with petroleum-ether and dried in a desiccator over $\mathrm{P}_{2} \mathrm{O}_{5}$. The product was crystallized. The compound (I) was obtained with the yield of $3.50 \mathrm{~g}(68 \%)$; $[\alpha]_{D}^{20}+9.5^{\circ}(c 1, \mathrm{MeOH}) ; R_{f} 0.55(\mathrm{~B}), 0.90(\mathrm{C})$.

HCl-H-BAla-Asp(OMe)-OMe (II). The $4.5 \mathrm{~N}$ solution of $\mathrm{HCl}(5.7 \mathrm{~mL})$ in ethyl acetate was added to the solution of compound (I) $(3.32 \mathrm{~g}, 10.0 \mathrm{mmol})$ in ethyl acetate $(2.0 \mathrm{~mL})$. The reaction mixture was stirred for $50 \mathrm{~min}$. The precipitate was filtered off, washed on a filter with ethyl acetate and ether, and dried in a desiccator over $\mathrm{NaOH}$. The yield of product (II) was $2.70 \mathrm{~g}(99 \%) ;[\alpha]_{D}^{20}-3.5^{\circ}(c 1, \mathrm{MeOH}) ; R_{f}$ 0.26 (A), 0.78 (B).

2-Acetoxybenzoyl-Arg (III). $N$-Hydroxysuccinimide $(0.63 \mathrm{~g}, 5.5 \mathrm{mmol})$ was added to the solution of $2-$ acetoxybenzoic acid $(0.90 \mathrm{~g}, 5.0 \mathrm{mmol})$ in dioxane $(5.0 \mathrm{~mL})$. The reaction mixture was cooled to $0^{\circ} \mathrm{C}$, and DCC $(1.23 \mathrm{~g}, 6.0 \mathrm{mmol})$ was added. The reaction mixture was stirred for $1 \mathrm{~h}$ while cooling and $2 \mathrm{~h}$ at room temperature. The precipitate of dicyclohexylurea was filtered off. The filtrate of $N$-hydroxysuccinimide ester of 2-acetoxybenzoic acid was added to the cooled aqueous solution $(4 \mathrm{~mL})$ of arginine $(0.65 \mathrm{~g}$, $3.7 \mathrm{mmol}$ ), and the reaction mixture was kept for $12 \mathrm{~h}$. Dioxane was evaporated, and the residue was diluted with acetone $(12.0 \mathrm{~mL})$. The crystalline precipitate of compound (III) was washed with ethyl acetate $(2 \times 3.0 \mathrm{~mL})$ and dried in vacuum over $\mathrm{P}_{2} \mathrm{O}_{5}$. The yield of the crystalline compound (III) was $0.98 \mathrm{~g}(79 \%) ; R_{f} 0.70$ (A), 0.58 (C); ESI mass spectrum, $m / z: 337.36[M+\mathrm{H}]^{+}$, $382.38[M+2 \mathrm{Na}]^{+}$.

2-Acetoxybenzoyl-Arg-BAla-Asp(OMe)-OMe (IV). 2-Acetoxybenzoyl-Arg (III) $(0.90 \mathrm{~g}, 2.7 \mathrm{mmol})$ was added to the solution of compound (II) $(0.67 \mathrm{~g}$, $2.7 \mathrm{mmol})$ in DMF $(3.5 \mathrm{~mL})$. The reaction mixture was stirred for $1 \mathrm{~h}$ and cooled to $0^{\circ} \mathrm{C}$. $\mathrm{HOBt}(0.38 \mathrm{~g}$, $2.8 \mathrm{mmol})$ and DIPC $(0.45 \mathrm{~mL}, 2.9 \mathrm{mmol})$ were sequentially added, and the reaction mixture was stirred for $3 \mathrm{~h}$ at $0^{\circ} \mathrm{C}$ and $4 \mathrm{~h}$ at room temperature. The precipitate was filtered off and washed on a filter with DMF $(0.5 \mathrm{~mL})$. Diethyl ether $(15.0 \mathrm{~mL})$ was added to the filtrate, and the precipitate was reprecipitated from methanol with ether. The product was purified by column chromatography on silica gel $60(0.02-0.045 \mathrm{~mm})$ in the mixture of chloroform, methanol, and water $(20: 24: 1)$. The fractions that contained the pure peptide were combined and evaporated. After the drying in a desiccator, compound (IV) was obtained with the yield of $0.68 \mathrm{~g}(49 \%) ; R_{f} 0.88(\mathrm{~A}), 0.91(\mathrm{C})$. The content of the target product was $98 \%$ according to HPLC. The ESI mass spectrum, $m / z: 551.69[M+\mathrm{H}]^{+}, 573.73$ $[M+\mathrm{Na}]^{+}$. 
2-Acetoxybenzoyl-Arg- $\beta$ Ala-Asp (V). To the solution of compound (IV) $(0.42 \mathrm{~g}, 0.8 \mathrm{mmol})$ in methanol $(9.7 \mathrm{~mL}), 2 \mathrm{~N} \mathrm{NaOH}(0.9 \mathrm{~mL})$ was added. After the hydrolysis was finished, the reaction mixture was acidified to $\mathrm{pH} 2-3$ with $4.5 \mathrm{~N}$ solution of $\mathrm{HCl}$ in ethyl acetate. The solvent was evaporated in vacuum to dryness. The residue was mixed with methanol $(2.0 \mathrm{~mL})$. The insoluble precipitate of $\mathrm{NaCl}$ was filtered off. The filtrate was mixed with anhydrous ether $(5.0 \mathrm{~mL})$. The product was reprecipitated from methanol with ether and dried in a desiccator over $\mathrm{P}_{2} \mathrm{O}_{5}$. Compound (V) was obtained with the yield of $0.39 \mathrm{~g}(89 \%)$; mp 95$97^{\circ} \mathrm{C} ; R_{f} 0.67$ (A), 0.57 (B). The ESI mass spectrum, $m / z$ : $523.69[M+\mathrm{H}]^{+}, 545.73[M+\mathrm{Na}]^{+} .{ }^{1} \mathrm{H} \mathrm{NMR}\left(\mathrm{CD}_{3} \mathrm{OD}\right)$ : $1.27\left(2 \mathrm{H}, \mathrm{m}, \mathrm{CHCH}_{2} \mathrm{CH}_{2} \mathrm{CH}_{2} \mathrm{NHC}(\mathrm{NH}) \mathrm{NH}_{2}\right), \quad 1.31$ $\left(2 \mathrm{H}, \mathrm{m}, \mathrm{CHCH}_{2} \mathrm{CH}_{2} \mathrm{CH}_{2} \mathrm{NHC}(\mathrm{NH}) \mathrm{NH}_{2}\right), 2.62(2 \mathrm{H}$, d, $\left.J 20, \mathrm{CH}_{2} \mathrm{COOH}\right), 2.73\left(3 \mathrm{H}, \mathrm{s}, \mathrm{OCOCH}_{3}\right), 2.84$ $\left(2 \mathrm{H}, \quad \mathrm{m}, \quad \mathrm{CHCH}_{2} \mathrm{CH}_{2} \mathrm{CH}_{2} \mathrm{NH}\right), 3.19(1 \mathrm{H}, \quad \mathrm{m}$, $\left.\mathrm{NHCH}\left(\mathrm{CH}_{2} \mathrm{CH}_{2} \mathrm{CH}_{2} \mathrm{NHC}(\mathrm{NH}) \mathrm{NH}_{2}\right) \mathrm{CO}\right), \quad 3.48$ $\left(1 \mathrm{H}, \mathrm{m}, \mathrm{CH}\left(\mathrm{CH}_{2} \mathrm{COOH}\right) \mathrm{COOH}\right), 3.70-3.75(4 \mathrm{H}$, $\left.\mathrm{m}, \quad \mathrm{HNC} \underline{\mathrm{H}}_{2} \underline{\mathrm{H}}_{2} \mathrm{CO}\right), \quad 7.21-7.87 \quad(4 \mathrm{H}, \mathrm{m}$, $\left.\mathrm{C}_{6} \mathrm{H}_{4}\left(\mathrm{OCOCH}_{3}\right) \mathrm{CO}\right)$.

Boc-4-aminobenzoyl-ßAla-Asp(OMe)-OMe (VI). TEA $(0.55 \mathrm{~mL}, 4.0 \mathrm{mmol})$ was added to the solution of compound (II) in DMF (3.5 mL). The reaction mixture was stirred for $20 \mathrm{~min}$, and Boc-4-aminobenzoic acid $(0.74 \mathrm{~g}, 3.1 \mathrm{mmol})$ was added. The reaction mixture was cooled to $0^{\circ} \mathrm{C}$, and HOBt $(0.43 \mathrm{~g}, 3.2 \mathrm{mmol})$ and DCC ( $0.76 \mathrm{~g}, 3.7 \mathrm{mmol})$ were sequentially added. The reaction mixture was stirred for $2 \mathrm{~h}$ at $0^{\circ} \mathrm{C}$ and 10 $\mathrm{h}$ at room temperature. The precipitate was filtered off and washed on a filter with DMF $(1.0 \mathrm{~mL})$. The filtrate was diluted with ethyl acetate $(10.0 \mathrm{~mL})$, washed with $9 \%$ solution of citric acid, $5 \%$ solution of $\mathrm{NaHCO}_{3}$, the saturated solution of $\mathrm{NaCl}$, and water, and dried over $\mathrm{Na}_{2} \mathrm{SO}_{4}$. Ethyl acetate was evaporated, and the residue was mixed with petroleum-ether $(7.0 \mathrm{~mL})$ and kept in the cold. The crystallized product was filtered and dried over $\mathrm{P}_{2} \mathrm{O}_{5}$. Compound (VI) was obtained with the yield of $1.20 \mathrm{~g}(86 \%) ; R_{f} 0.82(\mathrm{~B}), 0.88(\mathrm{C})$; the ESI mass spectrum, $m / z: 451.88[M]^{+}$.

Boc-4-aminobenzoyl-ßAla-Asp (VII) was prepared by saponification of compound (VI) $(1.00 \mathrm{~g}$, $2.2 \mathrm{mmol})$ with $2 \mathrm{~N}$ solution of $\mathrm{NaOH}(2.54 \mathrm{~mL})$ for $45 \mathrm{~min}$. The product was treated as described for compound $(\mathbf{V})$. The yield of the crystalline product (VII) was $0.83 \mathrm{~g}(89 \%) ; R_{f} 0.56(\mathrm{~B}), 0.77(\mathrm{C})$; the ESI mass spectrum, $m / z: 423.81[M]^{+}, 446.82[M+\mathrm{Na}]^{+}$.

HCl-4-aminobenzoyl-ßAla-Asp (VIII). The $4.5 \mathrm{~N}$ solution of $\mathrm{HCl}(6.8 \mathrm{~mL})$ in ethyl acetate was added to the solution of Boc-4-aminobenzoyl- $\beta$ Ala-Asp (VII) $(0.75 \mathrm{~g}, 1.7 \mathrm{mmol})$ in ethyl acetate $(2.0 \mathrm{~mL})$. The solution was stirred for $1 \mathrm{~h}$. The solvent was removed. The residue was twice washed with ether and dried in a desiccator over $\mathrm{NaOH}$. Compound (VII) was obtained with the yield of $0.63 \mathrm{~g}(98 \%) ; \mathrm{mp} 280-285^{\circ} \mathrm{C} ; R_{f} 0.53$ (A), 0.45 (C). The content of the target compound
(VII) was $98 \%$ according to HPLC. The ESI mass spectrum, $m / z: 323.38[M]^{+}, 359.83[M+\mathrm{Na}]^{+}$. ${ }^{1} \mathrm{H}$ NMR $\quad\left(\mathrm{CD}_{3} \mathrm{OD}\right), \quad \delta: \quad 1.20 \quad(2 \mathrm{H}, \quad \mathrm{t}, \quad J \quad 10$, $\left.\mathrm{NHCH}_{2} \mathrm{CH}_{2} \mathrm{CONH}\right), 2.50$ (2H, d, J 20, $\left.\mathrm{CH}_{2} \mathrm{COOH}\right)$, $3.52\left(2 \mathrm{H}, \mathrm{m}, \mathrm{NHCH}_{2} \mathrm{CH}_{2} \mathrm{CONH}\right), 4.65(1 \mathrm{H}, \mathrm{m}$, $\left.\mathrm{NHCH}(\mathrm{COOH}) \mathrm{CH}_{2} \mathrm{COOH}\right), 6.96,7.41$, and 7.91 $\left(4 \mathrm{H}, 3 \mathrm{~d}, J 5 ; 10 ; 5, \mathrm{NH}_{2}-\mathrm{C}_{6} \mathrm{H}_{4}-\mathrm{CO}\right)$.

Boc-4-piperidinecarbonyl- $\beta$ Ala-Asp(OMe)-OMe (IX). TEA (0.42 mL, $5.2 \mathrm{mmol})$ was added to the solution of compound (II) $(1.08 \mathrm{~g}, 4.0 \mathrm{mmol})$ in DMF $(4.5 \mathrm{~mL})$. The reaction mixture was stirred for $20 \mathrm{~min}$, and Boc-4-piperidinecarbonic acid $(0.92 \mathrm{~g}$, $4.0 \mathrm{mmol})$ was added. The reaction mixture was cooled to $0^{\circ} \mathrm{C}$, and $\mathrm{HOBt}(0.57 \mathrm{~g}, 4.2 \mathrm{mmol})$ and DCC $(0.99 \mathrm{~g}, 4.8 \mathrm{mmol})$ were sequentially added. The reaction mixture was stirred for $2 \mathrm{~h}$ at $0^{\circ} \mathrm{C}$ and $10 \mathrm{~h}$ at room temperature. An isolation and purification of compound (VIII) was performed as described for compound (VI). The yield of compound (VIII) proved to be $1.25 \mathrm{~g}(68.7 \%) ; R_{f} 0.78(\mathrm{~A}), 0.84(\mathrm{C})$. The ESI mass spectrum, $m / z: 443.36[M]^{+}, 466.38[M+$ $2 \mathrm{Na}]^{+}, 489.56[M+2 \mathrm{Na}]^{+}$.

Boc-4-piperidinecarbonyl-ßAla-Asp (X) was prepared by a saponification of compound (IX) $(0.96 \mathrm{~g}$, $2.1 \mathrm{mmol})$ with $2 \mathrm{~N}$ solution of $\mathrm{NaOH}(2.52 \mathrm{~mL})$ for $45 \mathrm{~min}$. The reaction mixture was treated as described for compound $(\mathbf{V})$. The yield of the crystalline product was $0.82 \mathrm{~g}(91 \%) ; R_{f} 0.53(\mathrm{~B}), 0.67(\mathrm{C})$. The ESI mass spectrum, $m / z: 415.38[M]^{+}, 438.36[M+\mathrm{Na}]^{+}$.

HCl 4-piperidinecarbonyl-BAla-Asp (XI). The $4.5 \mathrm{~N}$ solution of $\mathrm{HCl}(7.0 \mathrm{~mL})$ in ethyl acetate was added to the solution of Boc-4-piperidinecarbonylBAla-Asp (X) $(0.75 \mathrm{~g}, 1.8 \mathrm{mmol})$ in ethyl acetate $(2.0$ $\mathrm{mL}$ ). The solution was stirred for $1 \mathrm{~h}$ and the solvent was removed. The residue was washed with ether two times and dried in a desiccator over $\mathrm{NaOH}$. Compound $(\mathbf{X})$ was obtained with the yield of $0.61 \mathrm{~g}(97 \%)$; mp $120-122^{\circ} \mathrm{C} ; R_{f} 0.58(\mathrm{~A}), 0.34(\mathrm{C})$. The content of the target substance (X) was $98 \%$ according to HPLC. The ESI mass spectrum, $m / z: 338.32[M+\mathrm{Na}]^{+}, 361.38[M+$ $2 \mathrm{Na}]^{+} .{ }^{1} \mathrm{H}$ NMR $\left(\mathrm{CD}_{3} \mathrm{OD}\right) \delta: 1.28\left(1 \mathrm{H}, \mathrm{q}, J 10, \mathrm{CH}_{2}-\right.$ $\left.\mathrm{C} \underline{H}-\mathrm{CH}_{2 \text { piperidine }}\right), \quad 1.92-2.02 \quad\left(4 \mathrm{H}, \mathrm{m}, \quad \mathrm{CH}_{2}-\mathrm{CH}-\right.$ $\mathrm{C}_{2}$ piperidine $), 2.87$ (2H, m, $\left.\mathrm{NHCH}_{2} \mathrm{CH}_{2} \mathrm{CONH}\right), 3.06$ $\left(2 \mathrm{H}, \mathrm{t}, J 15, \mathrm{NHCH}_{2} \mathrm{CH}_{2} \mathrm{CONH}\right), 3.47(4 \mathrm{H}, \mathrm{m}$, $\left.\mathrm{C}_{2} \mathrm{NHC}_{2} \underline{\mathrm{H}}_{2 \text { piperidine }}\right), 3.74\left(2 \mathrm{H}, \mathrm{d}, J 20, \mathrm{C}_{2} \mathrm{COOH}\right)$, $4.18\left(1 \mathrm{H}, \mathrm{m}, \mathrm{NHC} \underline{\mathrm{H}}(\mathrm{COOH}) \mathrm{CH}_{2} \mathrm{COOH}\right)$.

Inhibition of the ADP-induced platelet aggregation in vitro. The platelet aggregation was investigated with the use of the platelet-enriched plasma (TEP). The plasma was taken by the informed consent of donors. We used only plastic or silicon cuvettes, tubes, or pipettes in order to exclude a contact activation of platelets. The donor blood was mixed with $3.8 \%$ solution of sodium citrate in a volume ratio of $9: 1$ and centrifuged at low revolutions ( $7 \mathrm{~min}$ at $200 \mathrm{~g}$ ). The TEP supernatant was placed in a plastic container. The 
residual blood was centrifuged for $15 \mathrm{~min}$ at $2000 \mathrm{~g}$. The upper layer after the repetitive centrifugation consisted of a platelet-free plasma. TEP was used for an investigation of the platelet functional activity. The plateletfree plasma was applied to a calibration of the optical density scale of a device and, if necessary, for a dilution of TEP to the standard content of the cells (200300 thousand platelets per microliter). The platelet aggregation was induced by an addition of the ADP agonist in a final concentration of $2.5 \mu \mathrm{M}$ and recorded by the Born turbodimetry method [19] on an AP 2110 aggregometer (Solar, Belarus). In a control experiment, TEP $(300 \mu \mathrm{L})$ was incubated with the $0.9 \%$ solution of sodium chloride $(30 \mu \mathrm{L})$ for $2 \mathrm{~min}$ at $37^{\circ} \mathrm{C}$. During the experiments, the examined compound in a concentration of $10^{-5} \mathrm{M}$ in the $0.9 \%$ solution of sodium chloride was added to TEP $(300 \mu \mathrm{L})$. Further, ADP $(30 \mu \mathrm{L})$ was added and the aggregation was observed for $10 \mathrm{~min}$. The experiments were repeated.

The surface markers of platelets were determined by flow cytofluorimetry (BD FACSCantoII). The platelets were obtained by the method of an automatic plateletpheresis in the Department of Extracorporal Treatment Modes of the Minsk Scientific and Practical Center of Surgery, Transplantology, and Hematology by the informed consent of donors. The thromboconcentrate $(500 \mu \mathrm{L})$ was mixed with the solution of the examined compound $\left(10^{-5} \mathrm{M}, 500 \mu \mathrm{L}\right)$ in $0.9 \%$ sodium chloride in an experimental tube. The control tube contained the $0.9 \%$ solution of sodium chloride. The initial concentration of platelets in the thromboconcentrate was $698.5(582.0 ; 786.5) \times 10^{9} / \mathrm{L}$. The data was presented as a median $(25 \mathrm{pr} ; 75 \mathrm{pr})$. The statistical analysis of the difference between the expression of the marker on the platelets of the control and the experimental samples was performed by the Friedman test.

\section{CONCLUSIONS}

The analogs of the Arg- $\beta$ Ala-Asp sequence which could effectively inhibit the platelet aggregation were prepared. These compounds were promising for further studies as potential antithrombotic agents.

\section{COMPLIANCE WITH ETHICAL STANDARDS}

All the procedures of this study involving human participants were performed in accordance with the ethical principles of the National Committee and the committee of the organization where the study was performed and in concordance with the Declaration of Helsinki (1964) and its subsequent changes or comparable ethical standards.

This article does not contain any studies involving animals performed by any of the authors.

\section{Conflict of Intersts}

The authors declare that they have no conflicts of interest.

\section{OPEN ACCESS}

This article is licensed under a Creative Commons Attribution 4.0 International License, which permits use, sharing, adaptation, distribution and reproduction in any medium or format, as long as you give appropriate credit to the original author(s) and the source, provide a link to the Creative Commons licence, and indicate if changes were made. The images or other third party material in this article are included in the article's Creative Commons licence, unless indicated otherwise in a credit line to the material. If material is not included in the article's Creative Commons licence and your intended use is not permitted by statutory regulation or exceeds the permitted use, you will need to obtain permission directly from the copyright holder. To view a copy of this licence, visit http://creativecommons.org/licenses/by/4.0/.

\section{REFERENCES}

1. Hynes, R.O., Cell, 1987, vol. 48, pp. 549-554. https://doi.org/10.1016/0092-8674(87)90233-9

2. Plow, E.F., Pierschbacher, M.D., and Ruoslahti, E., Proc. Natl. Acad. Sci. U. S. A., 1986, vol. 83, pp. 60026006.

https://doi.org/10.1073/pnas.83.16.6002

3. Pierschbacher, M.D. and Ruoslahti, E., Nature, 1984, vol. 309, pp. 30-33.

https://doi.org/10.1038/309030a0

4. Zablocki, J.A., Miyano, M., Garland, R.B., Pireh, D., Schretzman, L., Rao, S.N., Lindmark, R.J., PanzerKnodle, S.G., Nicholson, N.S., and Taite, B.B., $J$. Med. Chem., 1993, vol. 36, pp. 1811-1819.

https://doi.org/10.1021/jm00065a003

5. Miyashita, M., Akamatsu, M., Hayashi, Y., and Ueno, T., Bioorg. Med. Chem. Lett., 2000, vol. 10, pp. 859-863. https://doi.org/10.1016/S0960-894X(00)00113-X

6. Cannon, C.P., Clin. Cardiol., 2003, vol. 26, pp. 358364.

https://doi.org/10.1002/clc.4950260803

7. Hirsh, J., Guidelines for Antithrombotic Therapy, Hamilton, Ontario: BC Decker Inc., 1999.

8. Topol, E.J., Moliterno, D.J., Herrmann, H.C., Powers, E.R., Grines, C.L., Cohen, D.J., Cohen, E.A., Bertrand, M., Neumann, F.J., Stone, G.W., DiBattiste, P.M., and Demopoulos, L., N. Engl. J. Med., 2001, vol. 344, pp. 1888-1894. http://doi:

https://doi.org/10.1056/NEJM200106213442502

9. Valgimigli, M., Campo, G., Percoco, G., Bolognese, L., Vassanelli, C., Colangelo, S., De Cesare, N., Rodriguez, E.A., Ferrario, M., Moreno, R., Piva, T., Sheiban, I., Pasquetto, G., Prati, F., Nazzaro, M.S., Parrinello, G., and Ferrari, R., JAMA, 2008, vol. 299, pp. $1788-1799$.

https://doi.org/10.1001/jama.299.15.joc 80026 
10. Sinnaeve, P.R., Alexander, J.H., Bogaerts, K., Belmans, A., Wallentin, L., Armstrong, P., Adgey, J.A., Tendera, M., Diaz, R., Soares-Piegas, L., Vahanian, A., Granger, C.B., and Van De Werf, F.J., Am. Heart J., 2004, vol. 147, pp. 993-998.

https://doi.org/10.1016/j.ahj.2003.12.028

11. Husted, S., Eur. Heart J., 2007, vol. 9, suppl. D, pp. D20-D27.

https://doi.org/10.1093/eurheartj/sum012

12. Bokarev, I.N., Protivotrombotsitarnaya terapiya $v$ klinicheskoi praktike. Metodicheskie rekomendatsii (Antiplatelet Therapy in Clinical Practice: Guidelines), Moscow: Newdiamad, 2007.

13. Mel'nik, O.V., Martinovich, V.P., and Golubovich, V.P., Russ. J. Bioorg. Chem., 2006, vol. 32, pp. 122-128. https://doi.org/10.1134/S1068162006020038

14. Pollina, E., J. Undergrad. Sci., 1996, vol. 3, pp. 119126.
15. Nicholson, N.S., Abood, N.A., Panzer-Knodle, S.G., Frederick, L.G., Page, J.D., Salyers, A.K., Suleymanov, O.D., Szalony, J.A., Taite, B.B., and Anders, R.J., Med. Res. Rev., 2001, vol. 21, pp. 211-226. https://doi.org/10.1002/med.1007

16. Kannan, M., Ahmad, F., and Saxena, R., Blood, 2019, vol. 37, pp. 1-9. https://doi.org/10.1016/j.blre.2019.05.007

17. Hechler, B. and Gachet, C., Thromb. Vasc. Biol., 2015, vol. 35, pp. 2307-2315. https://doi.org/10.1161/ATVBAHA.115.303395

18. Israels, S.J. and McMillan-Ward, E.M., J. Thromb. Haemost., 2005, vol. 93, pp. 311-318. https://doi.org/10.1160/TH04-08-0503

19. Born, G.V.R., Nature, 1962, vol. 194, pp. 927-929. https://doi.org/10.1038/194927b0

Translated by L. Onoprienko 